\title{
MULTIPLE ATTRIBUTE DECISION MAKING (MADM) BASED SCENARIOS
}

\author{
Sarfaraz HASHEMKHANI ZOLFANI a, Reza MAKNOON a, *, \\ Edmundas Kazimieras ZAVADSKAS b \\ a Technology Foresight Group, Department of Management, Science and Technology, Amirkabir Univer- \\ sity of Technology (Tehran Polytechnic), P.O. Box 1585-4413, Tehran, Iran \\ ${ }^{b}$ Research Institute of Smart Building Technologies, Vilnius Gediminas Technical University, \\ Sauletekio al. 11, LT-10223 Vilnius, Lithuania
}

Received 16 September 2015; accepted 24 November 2015

\begin{abstract}
Decision making takes into account a myriad of factors about the future topics, which often prove challenging and quite complicated. Multiple Attribute Decision-Making (MADM) methods still have not become powerful enough to help decision makers to adopt the best solutions regarding future issues. Different scenarios are suitable for developing an appropriate outlook toward different probable futures. Scenarios are not inherently quantitative, but recently different integrated quantitative methods have been incorporated with the processes in various studies. Previously, different types of scenario-based MADM methods have been presented in different studies, but they just considered each case separately. In those studies, MADM methods were only applied to evaluate the situation in scenario-based MADM. This research concentrates on another paradigm in applying scenarios to upcoming events, MADM methods in the new area are explored, and the concept, which is called MADM based scenarios, is presented. In different situations and scenarios, different MADM models will happen. New concepts about most useful criterion and applicable alternatives are introduced in this new approach for decision-making about the future. In addition, a general framework is proposed for applying MADM-based scenarios for unpredictable scenarios and situations, which can be almost controlled future in practice.
\end{abstract}

KEYWORDS: Multiple Attribute Decision Making (MADM); Scenario planning; MADM based scenarios; future; The most useful criterion; The most applicable alternative

\section{INTRODUCTION}

One of the most famous branches of operation research models is Multi-Criteria Decision Making (MCDM) which is divided into multiple objective decision making (MODM) and multiple attribute decision making (MADM) (Potvin et al. 2004; Rousis et al. 2008; Zavadskas, Turskis 2011; Liou, Tzeng 2012; Zavadskas et al. 2014).

In the new century, Multiple Attribute Decision Making (MADM) was considered as a multi-disciplinary methodology for solving problems and decision making in many fields including management science, social sciences, engineering issues, economics etc. (Behzadian et al. 2010, 2012; Ishizaka, Labib 2011; Chen, Li 2011; Chai et al. 2013; Wang et al. 2014; Aguezzoul 2014; Mardani et al. 2015).

* Corresponding author. E-mail: rmaknoon@yahoo.com
Nowadays, decision making about the future is in the focus of the data analysts and experts. Strategic decision-making is so complicated that evaluating the alternatives in the decision-making process about a topic is a challenge. The MADM framework is a valuable tool for making the best decisions. This framework classically could not answer all decision-maker needs; but in recent years, it has changed quite a lot due to the needs. Dynamic perspective and trend has added more in different studies with a different paradigm (Xu 2008; Lou et al. 2010; Campanella, Ribeiro 2011; Trutnevyte et al. 2012; Zhang 2012; Durbach, Stewart 2012a; Hashemkhani Zolfani et al. 2013; Tadic et al. 2014; Gonzalez-Prida et al. 2014; Jassbi et al. 2014). 
Scenario planning is considered a useful tool in the strategic management and future study fields for long-term planning and decision-making (Bradfield et al. 2005; Stelzer et al. 2015). In general, scenarios are valuable and useful for exploring the future and for strategic decision-making. Although scenarios are powerful, they are not quantitative, and this is one of the disadvantages of scenarios in practice.

Multiple Attribute Decision Analysis (MADM) and Scenario Planning are two consequential methodologies in the management science field (Stewart et al. 2013). Different situations result in different scenarios that will probably happen. In these situations, MADM methods cannot be as effective. In the next section, more explanations will be provided in terms of applying both MADM methods and scenarios altogether. In previous studies, scholars have tried to evaluate scenarios based on MADM methods.

Briefly, this research is designed based on a new paradigm in decision-making about future topics. MADM based scenarios will be introduced in this study. MADM based scenarios have a big difference in comparison to "Scenarios-based MADM" and that is the general perspective of this new approach. In the decision making about future issues, same MADM models should exist due to a number of scenarios. The most effective criterion and applicable alternative will be introduced as a key part of MADM-based scenarios. The last part of MADM-based scenarios is presenting a logical solving framework for decision making based on unpredictable scenarios (wild-card scenarios).

\section{LITERATURE REVIEW}

In this section, all past-related significant studies about the combination of the MADM methodology and scenario planning and other quantitative methodologies with scenario planning are presented as follow.

\subsection{MADM and scenario planning}

This study considers different projects, and for each of them, two scenarios are generated. The priority of each project is evaluated based on MADM and scenario planning concept.

Browne et al. (2010) presented a new perspective in evaluating scenarios and policies according to the MCDA framework. Scenarios were assessed generally, and the best scenario was selected among other scenarios. Supriyasilp et al. (2009) applied MCDA framework in hydropower development priorities.
Durbach and Stewart (2012b) focused on the analysis of scenarios with a general MADM framework and integrated fuzzy numbers. This research tried to consider more uncertainties in developing the model. Petit and Fraser (2012) worked on selecting the best energy-delivery system for hand-held stop drilling. They evaluated different scenarios for this aim and applied AHP as the methodology in the study.

Ribeiro et al. (2013) created a specialized MCDA model for evaluating future scenarios for the power generation sector in Portugal. Like authors of other previous studies, they considered some criteria for assessing scenarios based on the MCDA general framework. In this, research optimization models were applied in generating scenarios. Marzouk et al. (2013) concentrated on a feasibility study of projects based on Simos' procedure and the MADM framework. Construction projects considered as the case of study and different scenarios considered as the alternatives. The Weighted-Sum Model (WSM) was applied in this research.

Ram and Montibeller (2013) also worked on evaluating scenarios based on Multiple Criteria Decision Analysis (MCDA). The paper proposed scenario-based MCDA methods to identify robust choices. In addition, that research applied the MCDA framework to evaluate each scenario and checked the consistency for each scenario. Stewart et al. (2013) reviewed previous studies about scenario planning and MCDM together. Furthermore, some extensions added through the research article. For instance, meta-criteria were introduced as a combination between scenarios and primary criteria. In the new extension, each criterion can be examined in a different context of scenarios.

Chung and Kim (2014) considered fuzzy logic for evaluating the future. A decision-making method under complete uncertainty (DMCU) was used with fuzzy TOPSIS for robust final ranking. Different decades as separate scenarios for the future of climate changing were considered in the study. Results of TOPSIS and fuzzy TOPSIS were compared together for a greater reliability of results. Sawicka and Zak (2014) proposed a new approach to evaluating scenarios. A traditional MADM method ELECTRE III was combined with Bayes classifier to develop a new stochastic MCDM/A procedure. All scenarios were assessed based on this new approach and, eventually, they were ranked.

Štreimikiene et al. (2016) evaluated different scenarios about electricity generation technologies with a hybrid MADM model. AHP-ARAS was applied as the methodology of the research, and five different scenarios were analysed with the hybrid model. 


\subsection{Other quantitative methodologies and scenario planning}

Durbach and Stewart (2003) developed a model for scenario planning used in decision making under uncertainty. They worked on the integration of goal programming and scenario planning with an emphasis on conflict among criteria.

Weng et al. (2010) considered MCDM and scenarios together. In this research article, multiple objectives were measured for generating scenarios and, finally, the MCDM general model was applied in evaluating the created scenarios. The proposed model of this research was called an integrated scenario-based multi-criteria decision support system.

Liu et al. (2015a) investigated the scenario analysis for the urban transport of passengers in terms of energy consumption. In the stated research system, the dynamic approach was applied for the analysis of generated scenarios. All scenarios in the research were policy-based scenarios and the system-dynamic approach played a proper role in the decision-making process. Liu et al. (2015b) researched the scenario analysis for energy consumption in the 2020 vision and for China. The system dynamic model was applied in that study, and policy scenarios about emissions target were assessed.

Fasanghari et al. (2015) investigated the Data Envelopment Analysis (DEA) for scenario analysis. In this study, different strategies (actions) were considered as different decision-making units. P-robust group DEA and fuzzy credibility constrained programming DEA were applied.

\section{METHODOLOGICAL APPROACH}

In previous analyses, MADM structures were considered as a part of scenarios' structures. This research is considered to use scenarios as a minor part of the decision-making process. MADM structure should also be a major part of the process. Undoubtedly, the performance of the MADM framework will be changing in different periods. Formerly, MADM was considered only for a specific time or duration of time in a stable environment and situation. However, in reality, situations are constantly changing, and MADM models need to be considered dynamically to answer the existing needs. Making a decision about the dynamic future is a complicated issue in management science and strategic management perspectives. Nowadays, a new MADM model is needed to play this role in the decision science field.

Scenario planning is a useful methodology in strategic management and studies on futures, which has an explorative perspective. Scenarios provide appropriate points of view to consider all aspects of a decision-making topic. Scenario planning is generally qualitative and does not have a quantitative aspect.

Scenario planning and MCDM have been considered jointly by different researchers (Durbach, Stewart 2012a; Stewart 2005: chap. 11; Stewart et al. 2013; Durbach 2014). This research is quite different in its methodology. Considering different periods of time and situations in a special type of a multipleattribute decision-making process is especially complicated. How should a decision in a dynamic and uncertain situation be answered? Is it possible to make a better decision with different scenarios with the MADM framework? If so, what strategies are best in applying said methods and principles?

This research will answer these questions, and the process of MADM-based scenarios is illustrated in Figure 1.

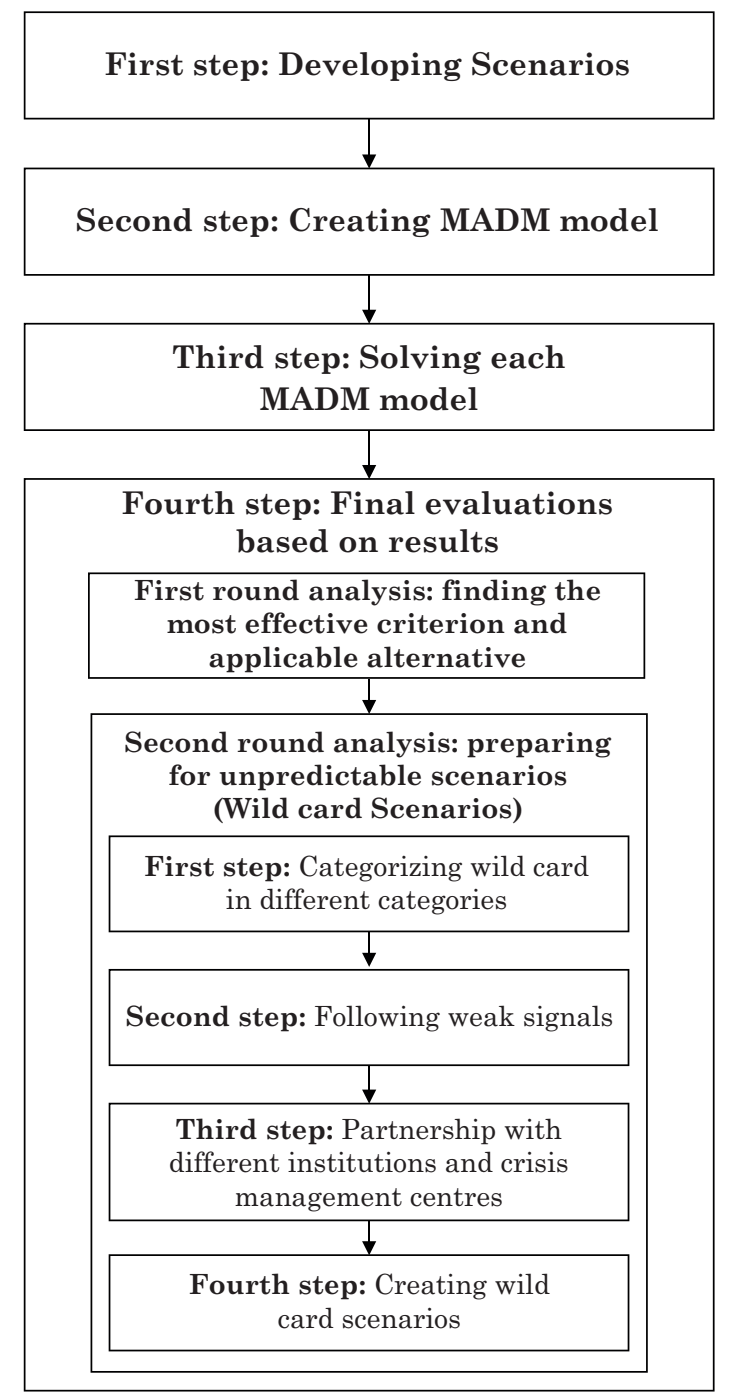

Fig. 1. The process of MADM-based scenarios 


\section{ILLUSTRATIVE EXAMPLE}

In this section, the new methodology will be examined with an example. Scenarios based on Multiple Attribute Decision Making is a new paradigm in decision-making, which is presented as a sub-field of MCDM, in general. The main difference between scenarios based on Multiple Attribute Decision Making (MADM) and scenario-based MADM is in the type of perspective behind this new paradigm that can be completely useful in decision making about topics and their future. This difference will show how different scenarios can make a difference meaning in MADM field and MADM methods.

Undoubtedly, in different scenarios issues cannot be fixed. Altered scenarios have different aspects, which can make a model. Criteria and alternatives will be changed due to different environments, situations, and scenarios. A challenge, which should be considered in solving these kinds of problems, is the way of thinking and solving the problem. Development of a framework for making a better decision in MADM-based scenarios needs to be analysed well. To achieve this goal, a powerful framework is developed in this research, which will be explained in more detail.

Making of an appropriate conclusion is considered as the best output for MADM-based scenarios. It is especially important when decision makers want to take the best decision about a vision of the future.

\subsection{Presenting methodology based on an example}

An example is established considering different aspects, which can happen in a real case. Next, it is described based on Figure 1.

\subsubsection{First step: developing scenarios}

Scenarios can be created based on different approaches and methodologies. In this research, the type of scenarios was not considered because the MADM approach is regarded as the core of the research and scenarios of all types can be helpful in the research process. In general, different situations can be considered as scenarios instead of developing scenarios. Hence, as an example, three different situations or scenarios are considered in this step. An MADM model should be considered for each situation or scenario, and finally, a general schematic form of MADM-based scenario is presented.

\subsubsection{Second step: creating the MADM model}

Due to each situation and scenario, evaluation can be very different. Alternatives and criteria can be dynamically changed according to different scenarios and situation. It can be concluded that each MADM model based on different scenarios can be a unique model with different alternatives and criteria. Different MADM methods can be applied in this section, and it does not have a direct impact on the structure of this study. Eventually, a decision-making matrix for each MADM model should be created based on the selected MADM method.

This research tries to illustrate all different probable situations. For this aim, scenarios are defined very dynamically in terms of criteria and alternatives. In each situation, the number, weights and definitions of criteria can be different. In addition, the situation for alternatives can be dynamically different. Alternatives can be evaluated differently due to different scenarios and situations. Therefore, this perspective to a topic is closer to real cases in comparison to previous classic perspectives in solving problems.

This section presents three scenarios, which are the general framework of studies on futures. Information about alternatives and criteria is presented in practice and tables. The decision matrix for each scenario is presented below:

\section{Scenario 1:}

Four alternatives are considered for this scenario. In addition, five criteria with different weights are again considered for this scenario. All information about the first scenario is shown in Table 1. For two other scenarios, the situation is different in a dynamic situation.

Table 1. Decision-making matrix for the first scenario

\begin{tabular}{llllll}
\hline Scenario 1 & $\mathrm{C}_{1}$ & $\mathrm{C}_{2}$ & $\mathrm{C}_{3}$ & $\mathrm{C}_{4}$ & $\mathrm{C}_{5}$ \\
\cline { 2 - 6 } & 0.25 & 0.2 & 0.3 & 0.15 & 0.1 \\
\cline { 2 - 6 } & $\operatorname{Min}$ & $\operatorname{Max}$ & $\operatorname{Max}$ & $\operatorname{Max}$ & Min \\
\hline $\mathrm{A}_{1}$ & 4 & 5 & 5 & 6 & 5 \\
$\mathrm{~A}_{2}$ & 7 & 8 & 7 & 8 & 7 \\
$\mathrm{~A}_{3}$ & 6 & 7 & 7 & 7 & 8 \\
$\mathrm{~A}_{4}$ & 5 & 7 & 5 & 7 & 6 \\
\hline
\end{tabular}

\section{Scenario 2:}

In this scenario, some changes happened. There are five alternatives in this scenario because there are more alternatives for this situation to be selected. Alternative 3 in the first scenario is not suitable enough to consider again as a probable alternative to be taken as a good solution in the decision-making process. In addition, six criteria are considered in this scenario. Some more changes also occurred in this scenario. Both criteria 2 and 4 are not mentioned in this scenario because they are not critical to consider as probable criteria for making the de- 
cision procedure. Hence, criteria 7 and 8 are added to the Table 2 . In addition, weights of criteria are changed depending on their importance in the newer scenario. All needed information about the decision matrix of scenario 2 is presented in Table 2 .

Table 2. Decision-making matrix for the second scenario

\begin{tabular}{lllllll}
\hline Scenario 2 & $\mathrm{C}_{1}$ & $\mathrm{C}_{7}$ & $\mathrm{C}_{3}$ & $\mathrm{C}_{8}$ & $\mathrm{C}_{5}$ & $\mathrm{C}_{6}$ \\
\cline { 2 - 7 } & 0.2 & 0.15 & 0.15 & 0.1 & 0.2 & 0.2 \\
\cline { 2 - 7 } & $\operatorname{Min}$ & $\operatorname{Max}$ & $\mathrm{Min}$ & $\mathrm{Max}$ & $\mathrm{Min}$ & $\mathrm{Max}$ \\
\hline $\mathrm{A}_{1}$ & 5 & 6 & 5 & 6 & 5 & 7 \\
$\mathrm{~A}_{2}$ & 8 & 6 & 7 & 7 & 7 & 7 \\
$\mathrm{~A}_{6}$ & 7 & 7 & 6 & 7 & 7 & 7 \\
$\mathrm{~A}_{4}$ & 5 & 8 & 8 & 7 & 5 & 8 \\
$\mathrm{~A}_{5}$ & 6 & 7 & 7 & 7 & 6 & 8 \\
\hline
\end{tabular}

\section{Scenario 3:}

In the last scenario, there are four alternatives, where a new alternative is considered as a potential alternative to the decision-making process. Also, just four criteria among previous criteria are considered as appropriate criteria for decision making in this scenario. Finally, weights of criteria have considered dynamically according to probable needs. More information about scenario 3 is demonstrated in Table 3.

Table 3. Decision-making matrix for the third scenario

\begin{tabular}{lllll}
\hline Scenario 3 & $\mathrm{C}_{1}$ & $\mathrm{C}_{2}$ & $\mathrm{C}_{5}$ & $\mathrm{C}_{8}$ \\
\cline { 2 - 5 } & 0.2 & 0.25 & 0.3 & 0.25 \\
\cline { 2 - 5 } & Min & Max & Min & Max \\
\hline $\mathrm{A}_{7}$ & 4 & 6 & 7 & 8 \\
$\mathrm{~A}_{2}$ & 7 & 7 & 7 & 7 \\
$\mathrm{~A}_{4}$ & 5 & 7 & 5 & 6 \\
$\mathrm{~A}_{6}$ & 6 & 8 & 7 & 7 \\
\hline
\end{tabular}

\subsubsection{Third step: solving each MADM model}

Each model should be calculated in this step. The calculation should be done based on the selected methodology. All scenarios and situations should be considered just based on one selected MADM method. In this study, WASPAS is selected for evaluating MADM models based on different scenarios. WASPAS is established based on Weighted Sum Model (WSM) and Weighted Product Model (WPM). Zavadskas et al. (2012) presented this methodology as a developed methodology with better accuracy in calculations and results. WASPAS as a new methodology in MADM methods has been recently applied in different fields such as:

- Civil and environmental engineering (Bagočius et al. 2014a,b; Zavadskas et al. 2013b; Dejus, Antucheviciene 2013; Šiožinytè, Antuchevicienè 2013; Bitarafan et al. 2014).

- Managerial decisions (Hashemkhani Zolfani et al. 2013; Chakraborty, Zavadskas 2014).

- Developing methodologies (Zavadskas et al. 2013a; Hashemkhani Zolfani et al. 2015).

All steps of the WASPAS methodology are as follow:

1. Normalized decision-making matrix based on:

$\bar{x}_{i j}=\frac{x_{i j}}{o p t_{i} x_{i j}}$, where $i=\overline{1, m} ; j=\overline{1, n} ;$

If opt value is max:

$\bar{x}_{i j}=\frac{o p t_{i} x_{i j}}{x_{i j}}$, where: $i=\overline{1, m} ; j=\overline{1, n}$;

If opt value is min:

2. Calculating WASPAS weighted and normalized decision-making matrix for the summarizing part:

$x_{i j, \text { sum }}=\bar{x}_{i j}, q_{j}$, where: $i=\overline{1, m} ; j=\overline{1, n}$;

3. Calculating WASPAS weighted and normalized decision-making matrix for the multiplication part:

$\overline{\bar{x}}_{i j, \text { mult }}=\bar{x}_{i j}^{q j}$, where: $i=\overline{1, m} ; j=\overline{1, n} ;$

4. The final calculation for evaluating and prioritizing alternatives based on:

$$
W P S_{i}=0.5 \sum_{j=1}^{n} \overline{\bar{X}} i j, \text { sum }+0.5 \prod_{j=1}^{n} \overline{\bar{X}}_{i j}, \text { mult },
$$

where $i=\overline{1, m} ; j=\overline{1, n}$.

\subsubsection{WASPAS results}

Scenarios and alternatives will be evaluated in this section. During the first step, decision-making matrixes based on three scenarios were established. Decision-making matrixes are shown in Tables 4-7. Each scenario is considered separately in this level and methodology can be done based on the classic methodology of WASPAS.

Table 4. Normalized decision-making matrix for the first scenario

\begin{tabular}{llllll}
\hline Scenario 1 & $\mathrm{C}_{1}$ & $\mathrm{C}_{2}$ & $\mathrm{C}_{3}$ & $\mathrm{C}_{4}$ & $\mathrm{C}_{5}$ \\
\cline { 2 - 6 } & 0.25 & 0.2 & 0.3 & 0.15 & 0.1 \\
\cline { 2 - 6 } & $\operatorname{Min}$ & $\operatorname{Max}$ & $\operatorname{Max}$ & $\operatorname{Max}$ & Min \\
\hline $\mathrm{A}_{1}$ & 1.000 & 0.625 & 0.714 & 0.750 & 1.000 \\
$\mathrm{~A}_{2}$ & 0.571 & 1.000 & 1.000 & 1.000 & 0.714 \\
$\mathrm{~A}_{3}$ & 0.667 & 0.875 & 1.000 & 0.875 & 0.625 \\
$\mathrm{~A}_{4}$ & 0.800 & 0.875 & 0.714 & 0.875 & 0.833 \\
\hline
\end{tabular}


Table 5. Normalized decision-making matrix for the second scenario

\begin{tabular}{lllllll}
\hline Scenario 2 & $\mathrm{C}_{1}$ & $\mathrm{C}_{7}$ & $\mathrm{C}_{3}$ & $\mathrm{C}_{8}$ & $\mathrm{C}_{5}$ & $\mathrm{C}_{6}$ \\
\cline { 2 - 7 } & 0.2 & 0.15 & 0.15 & 0.1 & 0.2 & 0.2 \\
\cline { 2 - 7 } & Min & Max & Min & Max & Min & Max \\
\hline $\mathrm{A}_{1}$ & 1.000 & 0.750 & 1.000 & 0.857 & 1.000 & 0.875 \\
$\mathrm{~A}_{2}$ & 0.625 & 0.750 & 0.714 & 1.000 & 0.714 & 0.875 \\
$\mathrm{~A}_{6}$ & 0.714 & 0.875 & 0.833 & 1.000 & 0.714 & 0.875 \\
$\mathrm{~A}_{4}$ & 1.000 & 1.000 & 0.625 & 1.000 & 1.000 & 1.000 \\
$\mathrm{~A}_{5}$ & 0.833 & 0.875 & 0.714 & 1.000 & 0.833 & 1.000 \\
\hline
\end{tabular}

Table 6. Normalized decision-making matrix for the third scenario

\begin{tabular}{lllll}
\hline Scenario 3 & $\mathrm{C}_{1}$ & $\mathrm{C}_{2}$ & $\mathrm{C}_{5}$ & $\mathrm{C}_{8}$ \\
\cline { 2 - 5 } & 0.2 & 0.25 & 0.3 & 0.25 \\
\cline { 2 - 5 } & Min & Max & Min & Max \\
\hline $\mathrm{A}_{7}$ & 1.000 & 0.750 & 0.714 & 1.000 \\
$\mathrm{~A}_{2}$ & 0.571 & 0.875 & 0.714 & 0.875 \\
$\mathrm{~A}_{4}$ & 0.800 & 0.875 & 1.000 & 0.750 \\
$\mathrm{~A}_{6}$ & 0.667 & 1.000 & 0.714 & 0.875 \\
\hline
\end{tabular}

In this part, decision-making matrixes are normalized for WASPAS methodology. Tables 7-9 illustrate the weighted and normalized matrix for the summarizing part. The multiplication part is be presented next.

Table 7. Weighted and normalized decision-making matrix for the summarizing part (first scenario)

\begin{tabular}{llllll}
\hline Scenario 1 & $\mathrm{C}_{1}$ & $\mathrm{C}_{2}$ & $\mathrm{C}_{3}$ & $\mathrm{C}_{4}$ & $\mathrm{C}_{5}$ \\
\hline $\mathrm{A}_{1}$ & 0.250 & 0.125 & 0.214 & 0.113 & 0.100 \\
$\mathrm{~A}_{2}$ & 0.143 & 0.200 & 0.300 & 0.150 & 0.071 \\
$\mathrm{~A}_{3}$ & 0.167 & 0.175 & 0.300 & 0.131 & 0.063 \\
$\mathrm{~A}_{4}$ & 0.200 & 0.175 & 0.214 & 0.131 & 0.083 \\
\hline
\end{tabular}

Table 8. Weighted and normalized decision-making matrix for the summarizing part (second scenario)

\begin{tabular}{lllllll}
\hline Scenario 2 & $\mathrm{C}_{1}$ & $\mathrm{C}_{7}$ & $\mathrm{C}_{3}$ & $\mathrm{C}_{8}$ & $\mathrm{C}_{5}$ & $\mathrm{C}_{6}$ \\
\hline $\mathrm{A}_{1}$ & 0.200 & 0.113 & 0.150 & 0.086 & 0.200 & 0.175 \\
$\mathrm{~A}_{2}$ & 0.125 & 0.113 & 0.107 & 0.100 & 0.143 & 0.175 \\
$\mathrm{~A}_{6}$ & 0.143 & 0.131 & 0.125 & 0.100 & 0.143 & 0.175 \\
$\mathrm{~A}_{4}$ & 0.200 & 0.150 & 0.094 & 0.100 & 0.200 & 0.200 \\
$\mathrm{~A}_{5}$ & 0.167 & 0.131 & 0.107 & 0.100 & 0.167 & 0.200 \\
\hline
\end{tabular}

Table 9. Weighted and normalized decision-making matrix for the summarizing part (third scenario)

\begin{tabular}{lllll}
\hline Scenario 3 & $\mathrm{C}_{1}$ & $\mathrm{C}_{2}$ & $\mathrm{C}_{5}$ & $\mathrm{C}_{8}$ \\
\hline $\mathrm{A}_{7}$ & 0.200 & 0.188 & 0.214 & 0.250 \\
$\mathrm{~A}_{2}$ & 0.114 & 0.219 & 0.214 & 0.219 \\
$\mathrm{~A}_{4}$ & 0.160 & 0.219 & 0.300 & 0.188 \\
$\mathrm{~A}_{6}$ & 0.133 & 0.250 & 0.214 & 0.219 \\
\hline
\end{tabular}

Weighted and normalized matrixes for the multiplication part are illustrated according to the third section of the WASPAS methodology in Tables 10-12.

Table 10. Weighted and normalized decision-making matrix for the multiplication part (first scenario)

\begin{tabular}{llllll}
\hline Scenario 1 & $\mathrm{C}_{1}$ & $\mathrm{C}_{2}$ & $\mathrm{C}_{3}$ & $\mathrm{C}_{4}$ & $\mathrm{C}_{5}$ \\
\hline $\mathrm{A}_{1}$ & 1.000 & 0.910 & 0.904 & 0.958 & 1.000 \\
$\mathrm{~A}_{2}$ & 0.869 & 1.000 & 1.000 & 1.000 & 0.967 \\
$\mathrm{~A}_{3}$ & 0.904 & 0.974 & 1.000 & 0.980 & 0.954 \\
$\mathrm{~A}_{4}$ & 0.946 & 0.974 & 0.904 & 0.980 & 0.982 \\
\hline
\end{tabular}

Table 11. Weighted and normalized decision-making matrix for the multiplication part (second scenario)

\begin{tabular}{lllllll}
\hline Scenario 2 & $\mathrm{C}_{1}$ & $\mathrm{C}_{7}$ & $\mathrm{C}_{3}$ & $\mathrm{C}_{8}$ & $\mathrm{C}_{5}$ & $\mathrm{C}_{6}$ \\
\hline $\mathrm{A}_{1}$ & 1.000 & 0.958 & 1.000 & 0.985 & 1.000 & 0.974 \\
$\mathrm{~A}_{2}$ & 0.910 & 0.958 & 0.951 & 1.000 & 0.935 & 0.974 \\
$\mathrm{~A}_{6}$ & 0.935 & 0.980 & 0.973 & 1.000 & 0.935 & 0.974 \\
$\mathrm{~A}_{4}$ & 1.000 & 1.000 & 0.932 & 1.000 & 1.000 & 1.000 \\
$\mathrm{~A}_{5}$ & 0.964 & 0.980 & 0.951 & 1.000 & 0.964 & 1.000 \\
\hline
\end{tabular}

Table 12. Weighted and normalized decision-making matrix for the multiplication part (third scenario)

\begin{tabular}{lllll}
\hline Scenario 3 & $\mathrm{C}_{1}$ & $\mathrm{C}_{2}$ & $\mathrm{C}_{5}$ & $\mathrm{C}_{8}$ \\
\hline $\mathrm{A}_{7}$ & 1.000 & 0.931 & 0.904 & 1.000 \\
$\mathrm{~A}_{2}$ & 0.894 & 0.967 & 0.904 & 0.967 \\
$\mathrm{~A}_{4}$ & 0.956 & 0.967 & 1.000 & 0.931 \\
$\mathrm{~A}_{6}$ & 0.922 & 1.000 & 0.904 & 0.967 \\
\hline
\end{tabular}

The last part is about final evaluating and ranking of the alternatives. All three scenarios and alternatives are shown in Table 13. The information about scenarios is separated but presented just in one table. Table 13 presents the general view of the scenarios.

Table 13. Results-based scenarios

\begin{tabular}{llllll}
\hline Scenarios & $\begin{array}{l}\text { Alter- } \\
\text { na- } \\
\text { tives }\end{array}$ & $0.5 \sum_{J=1}^{N} \overline{\bar{x}}_{i j}$ & $0.5 \prod_{j=1}^{n} \overline{\bar{x}}_{i j}$ & $\mathrm{WSP}_{\mathrm{i}}$ & $\begin{array}{l}\text { Rank- } \\
\text { ing }\end{array}$ \\
\hline Scenario 1 & $\mathrm{A}_{1}$ & 0.401 & 0.394 & 0.795 & 4 \\
& $\mathrm{~A}_{2}$ & 0.432 & 0.420 & 0.852 & 1 \\
& $\mathrm{~A}_{3}$ & 0.418 & 0.411 & 0.829 & 2 \\
& $\mathrm{~A}_{4}$ & 0.402 & 0.401 & 0.803 & 3 \\
Scenario 2 & $\mathrm{A}_{1}$ & 0.462 & 0.459 & 0.921 & 2 \\
& $\mathrm{~A}_{2}$ & 0.381 & 0.377 & 0.756 & 5 \\
& $\mathrm{~A}_{6}$ & 0.408 & 0.406 & 0.814 & 4 \\
& $\mathrm{~A}_{4}$ & 0.472 & 0.466 & 0.938 & 1 \\
& $\mathrm{~A}_{5}$ & 0.436 & 0.433 & 0.869 & 3 \\
Scenario 3 3 & $\mathrm{~A}_{7}$ & 0.426 & 0.421 & 0.847 & 2 \\
& $\mathrm{~A}_{2}$ & 0.383 & 0.378 & 0.761 & 4 \\
& $\mathrm{~A}_{4}$ & 0.433 & 0.430 & 0.863 & 1 \\
& $\mathrm{~A}_{6}$ & 0.408 & 0.403 & 0.811 & 3 \\
\hline
\end{tabular}


In the next section, the main contribution of this study will be described carefully in detail, which can help to understand what exactly MADM based scenarios are.

\subsubsection{Fourth step: final evaluations based on results}

The last step of this new concept is about evaluating all information and results in the best way. Presenting all data together is considered as the first step in the final evaluation. Weights of criteria are shown in Table 14. It is easier to put all information together for making a better decision.

Table 14. Weights of criteria based on the scenarios

\begin{tabular}{lllllllll}
\hline & $\mathrm{C}_{1}$ & $\mathrm{C}_{2}$ & $\mathrm{C}_{3}$ & $\mathrm{C}_{4}$ & $\mathrm{C}_{5}$ & $\mathrm{C}_{6}$ & $\mathrm{C}_{7}$ & $\mathrm{C}_{8}$ \\
\hline Scenario 1 & 0.25 & 0.2 & 0.3 & 0.15 & 0.1 & - & - & - \\
Scenario 2 & 0.2 & - & 0.15 & - & 0.2 & 0.2 & 0.15 & 0.1 \\
Scenario 3 & 0.2 & 0.25 & - & - & 0.3 & - & - & 0.25 \\
\hline
\end{tabular}

In addition, Table 15 is designed to illustrate all information about alternatives and priorities based on WASPAS methodology results.

Table 15. All information about alternatives and priorities in the scenarios

\begin{tabular}{llllllll}
\hline & $\mathrm{A}_{1}$ & $\mathrm{~A}_{2}$ & $\mathrm{~A}_{3}$ & $\mathrm{~A}_{4}$ & $\mathrm{~A}_{5}$ & $\mathrm{~A}_{6}$ & $\mathrm{~A}_{7}$ \\
\hline Scenario 1 & 4 & 1 & 2 & 3 & - & - & - \\
Scenario 2 & 2 & 5 & - & 1 & 3 & 4 & - \\
Scenario 3 & - & 4 & - & 1 & - & 3 & 2 \\
\hline
\end{tabular}

4.1.4.1. First round analysis: finding the most effective criterion and applicable alternative

The first action in the final analysis part is finding the most influential criterion and applicable alternative. How should they be considered? The answer is, the same forms exist due to the number of scenarios. As it can be seen in Table 14, two criteria (one and five) are critical in all scenarios, and it can be concluded that these are the most effective criteria in comparison to others. Moreover, the process is the same for Table 15. Both alternatives, two and four, are active in all scenarios. Hence, these two alternatives can be considered as the most applicable alternatives. Table 16 is the shown priority of criteria based on their effectiveness. Weights of criteria based on different scenarios are presented as well.

The possibility rate about the occurrence of a scenario is considered in this part. This rate is predicted by experts, methods of analysis etc. The possibility rate can be easily added to calculations.

The same as criteria, alternatives are evaluated based on applicability. The final priority based on their applicability is illustrated in Table 16.

\subsubsection{Second round analysis: preparing for unpredictable scenarios (wild card scenarios)}

As presented in the previous section, all probable scenarios can be considered, but some scenarios

Table 16. Investigation on effectiveness of criteria based on scenarios

\begin{tabular}{lllll}
\hline & Impact on scenarios & Average weights & Weights based on effectiveness & Ranking based on effectiveness \\
\hline $\mathrm{C}_{1}$ & 3 of $3=\% 100$ & 0.217 & $0.217 * 1=0.217$ & 1 \\
$\mathrm{C}_{2}$ & 2 of $3=\% 66.67$ & 0.225 & $0.225 * 0.6667=0.150$ & 3 \\
$\mathrm{C}_{3}$ & 2 of $3=\% 66.67$ & 0.225 & $0.225 * 0.6667=0.150$ & 3 \\
$\mathrm{C}_{4}$ & 1 of $3=\% 33.34$ & 0.15 & $0.15 * 0.3334=0.050$ & 7 \\
$\mathrm{C}_{5}$ & 3 of $3=\% 100$ & 0.2 & $0.2 * 1=0.2$ & 2 \\
$\mathrm{C}_{6}$ & 1 of $3=\% 33.34$ & 0.2 & $0.2 * 0.3334=0.067$ & 6 \\
$\mathrm{C}_{7}$ & 1 of $3=\% 33.34$ & 0.15 & $0.15 * 0.3334=0.050$ & 7 \\
$\mathrm{C}_{8}$ & 2 of $3=\% 66.67$ & 0.175 & $0.175 * 0.6667=0.117$ & 5 \\
\hline
\end{tabular}

Table 17. Investigation on effectiveness of criteria based on scenarios

\begin{tabular}{llllll}
\hline & $\begin{array}{l}\text { Applicability impact on } \\
\text { scenarios }\end{array}$ & $\begin{array}{l}\text { Priority based on } \\
\text { average }\end{array}$ & Primary ranking & $\begin{array}{l}\text { Weights based on ef- } \\
\text { fectiveness }\end{array}$ & $\begin{array}{l}\text { Priority based of ap- } \\
\text { plicability }\end{array}$ \\
\hline $\mathrm{A}_{1}$ & 2 of $3=\% 66.67$ & 3 & 4 & $3 / 0.6667=4.498$ & 3 \\
$\mathrm{~A}_{2}$ & 3 of $3=\% 100$ & 3.33 & 5 & $3.33 / 1=3.33$ & 2 \\
$\mathrm{~A}_{3}$ & 1 of $3=\% 33.34$ & 2 & 2 & $2 / 0.3334=5.989$ & 5 \\
$\mathrm{~A}_{4}$ & 3 of $3=\% 100$ & 1.667 & 1 & $1.667 / 1=1.667$ & 1 \\
$\mathrm{~A}_{5}$ & 1 of $3=\% 33.34$ & 3 & 4 & $3 / 0.3334=8.983$ & 7 \\
$\mathrm{~A}_{6}$ & 2 of $3=\% 66.67$ & 3.5 & 6 & $3.5 / 0.6667=5.250$ & 4 \\
$\mathrm{~A}_{7}$ & 1 of $3=\% 33.34$ & 2 & 2 & $2 / 0.3334=5.989$ & 5 \\
\hline
\end{tabular}


and cases cannot be even imagined. This type of unpredictable scenario is called a wild-card scenario. In the previous section, the most effective criterion and applicable alternative were identified. However, a question still remains open: can we predict everything that will happen in the future? The answer is no because some accidents can occur suddenly without any control of them. What can decision makers do with these situations? This is the last step and analysis section for MADMbased scenarios.

\subsection{First step: categorizing the wild card in different categories}

Categorizing can be considered as the first step toward reaching this aim of controlling unpredictable scenarios. Decision makers should consider different categories such as political, social concepts, movements, radical technological changes, militaries, and other situations in practice for a specific topic. This action can separate different complicated unpredictable situations into smaller parts, which can be easier to solve. This helps decision makers think better and concentrate.

\subsection{Second step: following weak signals}

Experts are needed for different critical categories and situations. Experts who are part of national and international movements in all aspects of different categories can be helpful in this section of the study. They can follow up weak signals in different categories. This can be one of the best solutions for controlling and monitoring the future. Eventually, control over weak signals can turn into controlling of wild card scenarios. Also, some scenarios can be created for weak signals but not necessarily.

\subsection{Third step: partnership with different} institutions and crisis management centres Once categorizing for identifying weak signals is improved, a partnership with critical institutions and centres seems necessary for controlling unpredictable futures. Making a decision about critical and vital topics needs a special attention. Decision makers should be more cautious about everything related to the future. A partnership can provide much suitable information for making a better decision. Being ready for unpredictable futures and scenarios needs appropriate cooperation among all data centres.

\subsection{Fourth step: creating wild card scenarios}

After completion of all previous sections, decision makers can provide some wild card scenarios. Being prepared for unpredictable futures is complicated and hard, but these types of scenarios can be useful preparing for the future. Undoubtedly, these scenarios will not be able to consider all future actions but can make some suitable abilities and potentials to control future happenings. These scenarios can be considered just as calculations for a most effective criterion and applicable alternative. These scenarios can be joined with the previous scenarios or considered completely separately, and this is related to decision makers' needs. This step, generally, can be considered more in future studies about MADM-based scenarios.

\section{CONCLUSIONS}

The study about future topics is critical. MADM models are valuable and useful methods for decision making at different levels of decision processes. Classical MADM models do not consider future in their concepts. There are some new trends in applying the future perspective in MADM calculation structures. As a quantitative structure, this framework is powerful and can be used in other qualitative methods. The MADM structure is flexible to be applied to other methods. This is the general paradigm for applying MADM with other methodologies in future studies.

Scenarios in both versions, planning and building, are especially powerful for exploring the futures. Scenarios are very useful but they are qualitative and can be considered as a disadvantage. Recently, different quantitative methodologies have been applied with scenarios in a wide range. These combinations are discussed in the literature review section. This new trend is in the developing phase and will be progressed continually until big changes.

Scenarios-based MCDM is one of the new combinations of these two fields but follows a different perspective. MCDM and especially MADM methods were applied to evaluating scenarios in practice for selecting the best scenario. This is not the general paradigm of this study and it can be seen easily in its structure. MADM framework is the main concept and scenarios just working as directors of structure, which means in a different situation and scenario, MADM model of decisionmaking can be dynamically changed. This study demonstrated how decisions can be made in such situations.

New definitions have been introduced for the final analysis of MADM-based scenarios, which have the most effective criterion and applicable alternative. With these steps, MADM-based scenarios were evaluated dynamically for all scenari- 
os and situations. As mentioned in Tables 16 and 17 , the final evaluation was done due to its special structure.

Eventually, wild card scenarios were considered for unpredictable situations and scenarios. This section answers a special need. A question is answered on how to apply MADM-based scenarios for these unpredictable situations. Four steps were designed to reach this aim and described in detail. This research presents a new paradigm in decision making about the future topics with applying both MADM models and scenarios in a suitable framework and can be considered in future studies as a new methodology.

Suggestions for probable future studies:

- Applying wild card scenarios as a test run with a case study.

- Developing a classical framework of MADM models for MADM-based scenario needs.

- Simulating scenarios based on MADM-based scenario approach in real cases with numerous probable situations in practice.

- Working in a multi-disciplinary manner on categories and their reasons (concentrating more on social, political and other constraints).

\section{REFERENCES}

Aguezzoul, A. 2014. Third-party logistics selection problem: a literature review on criteria and methods, Omega 49: 69-87. http://dx.doi.org/10.1016/j.omega.2014.05.009

Behzadian, M.; Kazemzadeh, R. B.; Albadvi, A.; Aghdasi, M. 2010. PROMETHEE: a comprehensive literature review on methodologies and applications, European Journal of Operational Research 200(1): 198-215. http://dx.doi.org/10.1016/j.ejor.2009.01.021

Behzadian, M.; Khanmohammadi Otaghsara, S.; Yazdani, M.; Ignatius, J. 2012. A state-of the-art survey of TOPSIS applications, Expert Systems with Applications 39(17): 13051-13069. http://dx.doi.org/10.1016/j. eswa.2012.05.056

Bagočius, V.; Zavadskas, E. K.; Turskis, Z. 2014a. Sequence determining of construction of the offshore wind farm construction applying permutation method, E\&M Ekonomie a Management 17(3): 50-61.

Bagočius, V.; Zavadskas, E. K.; Turskis, Z. 2014b. Multiperson selection of the best wind turbine based on the multi-criteria integrated additive-multiplicative utility function, Journal of Civil Engineering and Management 20(4): 590-599. http://dx.doi.org/10.38 46/13923730.2014.932836

Bitarafan, M.; Hashemkhani Zolfani, S.; Lale Arefi, S.; Zavadskas, E. K.; Mahmoudzadeh, A. 2014. Evaluation of real-time intelligent sensors for structural health monitoring of bridges based on SWARAWASPAS: a case in Iran, Baltic Journal of Road and Bridge Engineering 9(4): 333-340. http://dx.doi. org/10.3846/bjrbe.2014.40

Bradfield, R. G.; Wright, G.; Burt, C. G.; van der Heijden, K. 2005. The origins and evolution of scenario techniques in long range business planning, $F u$ tures 37(8): 795-812. http://dx.doi.org/10.1016/j.futures.2005.01.003

Browne, D.; O'Regan, B.; Moles, R. 2010. Use of multicriteria decision analysis to explore alternative domestic energy and electricity policy scenarios in an Irish city-region, Energy 35: 518-528. http://dx.doi. org/10.1016/j.energy.2009.10.020

Campanella, G.; Ribeiro, R. A. 2011. A framework for dynamic multiple-criteria decision making, Decision Support Systems 52: 52-60. http://dx.doi. org/10.1016/j.dss.2011.05.003

Chai, J.; Liu, J. N. K.; Ngai, E. W. T. 2013. Application of decision-making techniques in supplier selection: a systematic review of literature, Expert Systems with Applications 40(10): 3872-3885. http://dx.doi. org/10.1016/j.eswa.2012.12.040

Chakraborty, S.; Zavadskas, E. K. 2014. Applications of WASPAS method in manufacturing decision making, Informatica 25(1): 1-20. http://dx.doi.org/10.15388/ Informatica.2014.01

Chen, Y.; Li, B. 2011. Dynamic multi-attribute decision making model based on triangular intuitionistic fuzzy numbers, Scientia Iranica B18(2): 268-274. http://dx.doi.org/10.1016/j.scient.2011.03.022

Chung, E. S.; Kim, Y. 2014. Development of fuzzy multi-criteria approach to prioritize locations of treated wastewater use considering climate change scenarios, Journal of Environmental Management 146: 505516. http://dx.doi.org/10.1016/j.jenvman.2014.08.013

Dejus, T.; Antucheviciene, J. 2013. Assessment of health and safety solutions at a construction site, Journal of Civil Engineering and Management 19(5): 728-737. http://dx.doi.org/10.3846/13923730.2013.812578

Durbach, I. 2014. Outranking under uncertainty using scenarios, European Journal of Operational Research 232: 98-108. http://dx.doi.org/10.1016/j. ejor.2013.06.041

Durbach, I. N.; Stewart, T. J. 2012a. Modeling uncertainty in multi-criteria decision analysis, European Journal of Operational Research 223: 1-14. http:// dx.doi.org/10.1016/j.ejor.2012.04.038

Durbach, I.; Stewart, T. 2012b. A comparison of simplified value function approaches for treating uncertainty in multi-criteria decision analysis, Omega 40: 456464. http://dx.doi.org/10.1016/j.omega.2011.08.004

Durbach, I.; Stewart, T. 2003. Integrating scenario planning and goal programming, Journal of MultiCriteria Decision Analysis 12: 261-271. http://dx.doi. org/10.1002/mcda.362

Fasanghari, M.; Amalnick, M. S.; Taghipour Anvari, R.; Razmi, J. 2015. A novel credibility- based group decision making method for enterprise architecture scenario analysis using data envelopment analysis, Applied Soft Computing 32: 347-368. http://dx.doi. org/doi:10.1016/j.asoc.2015.03.052

Gonzalez-Prida, V.; Viveros, P.; Barbera, L.; Crespo Marquez, A. 2014. Dynamic analytic hierarchy process: 
AHP method adapted to a changing environment, Journal of Manufacturing Technology Management 24(4): 457-475.

Hashemkhani Zolfani, S.; Aghdaie, M. H.; Derakhti, A.; Zavadskas, E. K.; Morshed Varzandeh, M. H. 2013. Decision making on business issues with foresight perspective: an application of new hybrid MCDM model in shopping mall locating, Expert Systems with Applications 40: 7111-7121. http://dx.doi. org/10.1016/j.eswa.2013.06.040

Hashemkhani Zolfani, S.; Maknoon, R.; Zavadskas, E. K. 2015. Multiple Nash Equilibriums and evaluation of strategies. New application of MCDM methods, Journal of Business Economics and Management 16(2): 290-306. http://dx.doi.org/10.3846/1611 1699.2014.967715

Ishizaka, A.; Labib, A. 2011. Review of the main developments in the analytic hierarchy process, Expert Systems with Applications 38(11): 14336-14345. http://dx.doi.org/10.1016/j.eswa.2011.04.143

Jassbi, J. J.; Ribeiro, R. A.; Varela, L. R. 2014. Dynamic MCDM with future knowledge for supplier selection, Journal of Decision Systems 23(3): 232-248. http:// dx.doi.org/10.1080/12460125.2014.886850

Liou, J. J. H.; Tzeng, G. H. 2012. Comments on "Multiple criteria decision making (MCDM) methods in economics: an overview", Technological and Economic Development of Economy 18(4): 672-695. http:// dx.doi.org/10.3846/20294913.2012.753489

Liu, X.; Ma, S.; Tian, J.; Jia, N.; Li, G. 2015a. A system dynamics approach to scenario analysis for urban passenger transport energy consumption and CO2 emissions: a case study of Beijing, Energy Policy 85: 253-270. http://dx.doi.org/10.1016/j.enpol.2015.06.007

Liu, X.; Mao, G.; Ren, J.; Man Li, R. Y.; Guo, J.; Zhang, L. 2015b. How might China achieve its 2020 emissions target? A scenario analysis of energy consumption and $\mathrm{CO}_{2}$ emissions using the system dynamics model, Journal of Cleaner Production 103: 401-410. http://dx.doi.org/10.1016/j.jclepro.2014.12.080

Lou, C.; Kou, G.; Peng, Y.; Ge, X. 2010. DMCDM: a dynamic multi criteria decision making model for sovereign credit default risk evaluation, in $2^{\text {nd }}$ International Conference on Software Engineering and Data Mining (SEDM), 23-25 June 2010, Chengdu, 489-494.

Mardani, A.; Jusoh, A.; Zavadskas, E. K. 2015. Fuzzy multiple criteria decision-making techniques and applications - two decades review from 1994 to 2014, Expert Systems with Applications 42(8): 4126-4148. http://dx.doi.org/10.1016/j.eswa.2015.01.003

Marzouk, M.; Amer, O.; El-said, M. 2013. Feasibility study of industrial projects using Simos' procedure, Journal of Civil Engineering and Management 19(1): 59-68. http://dx.doi.org/10.3846/13923730.2012.734 855

Petit, P. J.; Fraser, P. D. 2012. What is the best energy delivery systems for hand-held stope drilling and associated equipment in narrow-reef hard rock mines?, in $5^{\text {th }}$ international platinum conference "A catalyst for change”, 17-21 September 2012, Sun City, South Africa, 1037-1053.
Potvin, J. Y.; Soriano, P.; Vallee, M. 2004. Generating trading rules on the stock markets with genetic programming, Computers and Operations Research 31: 1033-1047. http://dx.doi.org/10.1016/S03050548(03)00063-7

Ram, C.; Montibeller, G. 2013. Exploring the impact of evaluating strategic options in a scenario-based multi-criteria framework, Technological Forecasting \& Social Change 80: 657-672. http://dx.doi. org/10.1016/j.techfore.2012.09.019

Ribeiro, F.; Ferreira, P.; Araújo, M. 2013. Evaluating future scenarios for the power generation sector using a Multi-Criteria Decision Analysis (MCDA) tool: the Portuguese case, Energy 52: 126-136. http://dx.doi. org/10.1016/j.energy.2012.12.036

Rousis, K.; Moustakas, K.; Malamis, S.; Papadopoulos, A.; Loizidou, M. 2008. Multi-criteria analysis for the determination of the best WEEE management scenario in Cyprus, Waste Management 28: 19411954. http://dx.doi.org/10.1016/j.wasman.2007.12.001

Sawicka, H.; Zak, J. 2014. Ranking of distribution system's redesign scenarios using stochastic MCDM/A procedure, Procedia - Social and Behavioral Sciences 111: 186-196. http://dx.doi.org/10.1016/j.sbspro.2014.01.051

Šiožinytè, E.; Antuchevičienė, J. 2013. Solving the problems of daylighting and tradition continuity in a reconstructed vernacular building, Journal of Civil Engineering and Management 19(6): 873-882. http:// dx.doi.org/10.3846/13923730.2013.851113

Stelzer, B.; Meyer-Brötz, F.; Schiebel, E.; Brecht, L. 2015. Combining the scenario technique with bibliometrics for technology foresight: the case of personalized medicine, Technological Forecasting \& Social Change 98: 137-156. http://dx.doi.org/10.1016/j.techfore.2015.06.008

Stewart, T. 2005. Dealing with uncertainties in MCDA, in Figueira, J.; Greco, S.; Ehrgott, M. (Eds.). Multiple criteria decision analysis: state of the art surveys. International Series in Operations Research \& Management Science 78: 445-466.

Stewart, T. J.; French, S.; Rios, J. 2013. Integrating multi-criteria decision analysis and scenario planning - review and extension, Omega 41: 679-688. http://dx.doi.org/10.1016/j.omega.2012.09.003

Štreimikiene, D.; Šliogeriene, J.; Turskis, Z. 2016. Multicriteria analysis of electricity generation technologies in Lithuania, Renewable Energy 85: 148-156. http:// dx.doi.org/10.1016/j.renene.2015.06.032

Supriyasilp, T.; Pongput, K.; Bonyasirikul, T. 2009. Нydropower development priority using MCDM method, Energy Policy 37(5): 1866-1875. http://dx.doi. org/10.1016/j.enpol.2009.01.023

Tadic, S. R.; Zecevic, S. M.; Krstic, M. D. 2014. Ranking of logistics system scenarios for central business district, Promet - Traffic \& Transportation 26(2): 159-167.

Trutnevyte, E.; Stauffacher, M.; Scholz, R. W. 2012. Linking stakeholder visions with resource allocation scenarios and multi-criteria assessment, European Journal of Operational Research 219: 762-772. http://dx.doi.org/10.1016/j.ejor.2012.01.009 
$\mathrm{Xu}$, Z. 2008. On multi-period multi-attribute decision making, Knowledge-Based Systems 21(2): 164-171. http://dx.doi.org/10.1016/j.knosys.2007.05.007

Wang, Y.; Shi, X.; Sun, J.; Qian, W. 2014. A grey interval relational degree-based dynamic multi-attribute decision making method and its application in investment decision making, Mathematical Problems in Engineering 2014: 1-6. http://dx.doi. org/10.1155/2014/607016

Weng, S. Q.; Huang, G. H.; Li. Y. P. 2010. An integrated scenario-based multi-criteria decision support system for water resources management and planning a case study in the Haihe River Basin, Expert Systems with Applications 37: 8242-8254. http://dx.doi. org/10.1016/j.eswa.2010.05.061

Zavadskas, E. K.; Antuchevičienè, J.; Šaparauskas, J.; Turskis, Z. 2013a. Multi-criteria assessment of facades' alternatives: peculiarities of ranking methodology, Procedia Engineering 57: 107-112. http:// dx.doi.org/10.1016/j.proeng.2013.04.016

Zavadskas, E. K.; Antuchevičienè, J.; Šaparauskas, J.; Turskis, Z. 2013b. MCDM methods WASPAS and MULTIMOORA: verification of robustness of meth- ods when assessing alternative solutions, Economic Computation and Economic Cybernetics Studies and Research 47(2): 5-20.

Zavadskas, E. K.; Turskis, Z. 2011. Multiple criteria decision making (MCDM) methods in economics: an overview, Technological and Economic Development of Economy 17(2): 397-427. http://dx.doi.org/10.3846 /20294913.2011.593291

Zavadskas, E. K.; Turskis, Z.; Antuchevičienè, J.; Zakarevičius, A. 2012. Optimization of weighted aggregated sum product assessment, Electronics and Electrical Engineering 6(122): 3-6. http://dx.doi. org/10.5755/j01.eee.122.6.1810

Zavadskas, E. K.; Turskis, Z.; Kildienè, S. 2014. State of art surveys of overviews on MCDM/MADM methods, Technological and Economic Development of Economy 20(1): 165-179. http://dx.doi.org/10.3846/202949 13.2014.892037

Zhang, Z. 2012. An approach to dynamic multi-attribute decision making for choosing green supplier, Journal of Convergence Information Technology 7(21): 261269. http://dx.doi.org/10.4156/jcit.vol7.issue21.33 